\title{
Genesis of Dulong Sn-Zn-In Polymetallic Deposit in Yunnan Province, South China: Insights from Cassiterite U-Pb Ages and Trace Element Compositions
}

\author{
Shiyu Liu ${ }^{1,2}$, Yuping Liu ${ }^{1, *}$, Lin Ye ${ }^{1, *}$, Chen Wei ${ }^{1,2}$, Yi Cai $^{3}$ and Weihong Chen ${ }^{1,2}$ \\ 1 State Key Laboratory of Ore Deposit Geochemistry, Institute of Geochemistry, Chinese Academy of Sciences, \\ Guiyang 550081, China; liushiyu@mail.gyig.ac.cn (S.L.); weichen@mail.gyig.ac.cn (C.W.); \\ chenweihong@mail.gyig.ac.cn (W.C.) \\ 2 University of Chinese Academy of Sciences, Beijing 100049, China \\ 3 Institute for Ecological Civilization of Karst Area, Guizhou Normal University, Guiyang 550001, China; \\ enginecai@126.com \\ * Correspondence: liuyuping@vip.gyig.ac.cn (Y.L.); yelin@vip.gyig.ac.cn (L.Y.)
}

\section{check for} updates

Citation: Liu, S.; Liu, Y.; Ye, L.; Wei, C.; Cai, Y.; Chen, W. Genesis of Dulong Sn-Zn-In Polymetallic Deposit in Yunnan Province, South China: Insights from Cassiterite U-Pb Ages and Trace Element Compositions. Minerals 2021, 11, 199. https://doi.org/10.3390/ $\min 11020199$

Academic Editors: Huan Li and Maria Boni

Received: 18 January 2021

Accepted: 8 February 2021

Published: 13 February 2021

Publisher's Note: MDPI stays neutral with regard to jurisdictional claims in published maps and institutional affiliations.

Copyright: (c) 2021 by the authors. Licensee MDPI, Basel, Switzerland. This article is an open access article distributed under the terms and conditions of the Creative Commons Attribution (CC BY) license (https:/ / creativecommons.org/licenses/by/ $4.0 /)$.

\begin{abstract}
The Dulong Sn-Zn-In polymetallic deposit in the Yunnan province, SW China, hosts a reserve of $5.0 \mathrm{Mt} \mathrm{Zn}, 0.4 \mathrm{Mt} \mathrm{Sn}$, and $7 \mathrm{Kt} \mathrm{In}$. It is one of the most important polymetallic tin ore districts in China. Granites at Dulong mining area include mainly the Laojunshan granite (third phase), which occurs as quartz porphyry or granite porphyry dikes in the Southern edge of the Laojunshan intrusive complex. Granites of phases one and two are intersected at drill holes at depth. There are three types of cassiterite mineralization developed in the deposit: cassiterite-magnetite \pm sulfide ore (Cst I), cassiterite-sulfide ore (Cst II) within the proximal skarn in contact with the concealed granite (granites of phases one to two and three), and cassiterite-quartz vein ore (Cst III) near porphyritic granite. Field geology and petrographic studies indicate that acid neutralising muscovitization and pyroxene reactions were part of mechanisms for $\mathrm{Sn}$ precipitation resulting from fluid-rock interaction. In situ U-Pb dating of cassiterite samples from the ore stages of cassiterite-sulfide (Cst II) and Cassiterite-quartz vein (Cst III) yielded Tera-Wasserburg U-Pb lower intercept ages of $88.5 \pm 2.1 \mathrm{Ma}$ and $82.1 \pm 6.3 \mathrm{Ma}$, respectively. The two mineralization ages are consistent with the emplacement age of the Laojunshan granite (75.9-92.9 Ma) within error, suggesting a close temporal link between $\mathrm{Sn}-\mathrm{Zn}(-\mathrm{In})$ mineralization and granitic magmatism. LA-ICPMS trace element study of cassiterite indicates that tetravalent elements (such as $\mathrm{Zr}, \mathrm{Hf}, \mathrm{Ti}, \mathrm{U}, \mathrm{W}$ ) are incorporated in cassiterite by direct substitution, and the trivalent element $(\mathrm{Fe})$ is replaced by coupled substitution. CL image shows that the fluorescence signal of Cst I-II is greater than that of Cst III, which is caused by differences in contents of activating luminescence elements ( $\mathrm{Al}, \mathrm{Ti}, \mathrm{W}$, etc.) and quenching luminescence element (Fe). Elevated $\mathrm{W}$ and $\mathrm{Fe}$ but lowered $\mathrm{Zr}, \mathrm{Hf}, \mathrm{Nb}$, and Ta concentrations of the three type cassiterites from the Dulong Sn-Zn-In polymetallic deposit are distinctly different from those of cassiterites in VMS/SEDEX tin deposits, but similar to those from granite-related tin deposits. From cassiteritemagnetite \pm sulfide (Cst I), cassiterite-sulfide ore (Cst II), to cassiterite-quartz vein ore-stage (Cst III), high field strength elements (HFSEs: $\mathrm{Zr}, \mathrm{Nb}, \mathrm{Ta}, \mathrm{Hf}$ ) decrease. This fact combined with cassiterite crystallization ages, indicates that Cst I-II mainly related to concealed granite (Laojunshan granites of phases one and two) while Cst III is mainly related to porphyritic granite (Laojunshan granites of phase three).
\end{abstract}

Keywords: cassiterite U-Pb dating; trace elements; substitution mechanism; ore genesis; the Dulong Sn-Zn-In polymetallic deposit; South China

\section{Introduction}

Most of the worldwide tin mineralization is considered to be related to hydrothermal processes, which are associated with highly fractionated granites [1-3]. Cassiterite $\left(\mathrm{SnO}_{2}\right)$ 
is the most important tin ore mineral, which has a tetragonal lattice structure similar to that of rutile, wherein the $\mathrm{Sn}$ cations are in six-fold coordination with oxygen. Many trace elements, including $\mathrm{Mn}, \mathrm{Fe}, \mathrm{Ti}, \mathrm{Nb}, \mathrm{Ta}, \mathrm{Sc}, \mathrm{V}, \mathrm{Ga}, \mathrm{Cr}, \mathrm{Zr}, \mathrm{Hf}, \mathrm{W}, \mathrm{Sb}$, and $\mathrm{U}$ can be accommodated in the structure of cassiterite [4-6]. The enrichment of these elements in cassiterite is related to chemical conditions and the geological processes in the ore precipitation environment, ore-forming processes, and the nature of associated ore-forming fluids. These trace element abundances in cassiterite may be used to record the physicochemical information of ore-forming fluid and reflect upon the precipitation environment of cassiterite. However, the incorporated mechanism of trace elements in cassiterite is still debated [6-10]. Radioisotopic dating is a powerful tool to constrain the age of deposits and understanding of their ore genesis [11-15]. In recent decades, with the development of analytical techniques, reliable results have been obtained by LA-(MC)-ICPMS U-Pb dating on U-bearing minerals such as zircon, rutile, monazite, perovskite, titanite, allanite, columbite-tantalite, calcite and cassiterite $[6,9,10,16-20]$.

The Dulong Sn-Zn-In polymetallic deposit in the Yunnan province, Southwestern China, contains 5.0 Mt Zn, 0.4 Mt Sn, and 7 Kt In [21], and is one of the largest Sn-Zn-In deposits in South China. Previous radioisotopic dating results have shown that $\mathrm{Sn}-\mathrm{Zn}$ polymetallic mineralization in the Dulong mine area is genetically related to the Late Cretaceous Laojunshan granites [21-24]. However, the Laojunshan granites form a multiphase pluton. Cassiterite, as the main Sn-bearing mineral, is well developed at Dulong and it co-exists with the sulfides-oxide-silicate assemblage, but it remains unclear whether multi-stage Sn mineralizations at Dulong are related to the Laojunshan multi-phase pluton.

In this paper, detailed mineralogy, in-situ trace element and LA-ICP-MS U-Pb dating are used to investigate the cassiterite from Dulong, with the purpose of (1) constraining the precipitation mechanism of cassiterite; (2) examining the trace elements substitution mechanism in cassiterite; (3) determining the genesis of different types of cassiterites; (4) constraining the timing of tin mineralization in the Dulong deposit.

\section{Geological Background}

The South China Block consists of the Cathaysia Block in the Southeast and Yangtze Block in the Northwest (Figure 1a [25]). The Dulong Sn-Zn polymetallic ore district occurs at the Western margin of the Cathaysia Block at the junction of the Yangtze Block in the North (Figure 1a). It is located in the Southwestern portion of the Laojunshan Metamorphic Core Complex (Figure 1b) which primarily consists of metamorphic rocks (Paleoproterozoic Mengdong Group and Neoproterozoic Xinzhaiyan Formation), sedimentary rocks (Cambrian and Devonian), and granites (Silurian and Cretaceous) (Figure 1b [26]). The Paleoproterozoic Mengdong Group is dominated by two-mica quartz schists, two-mica schists, plagiogneiss, plagio-amphibolites, and granulites. Previous results indicated SHRIMP zircon $\mathrm{U}-\mathrm{Pb}$ ages of 761-829 Ma [26]. The Silurian granite gives LA-ICP-MS zircon U-Pb ages of 426 to $438 \mathrm{Ma}$ [27], which is exposed in the Eastern part of the study area and has been metamorphosed and deformed at $\sim 237 \mathrm{Ma}$ [28]. The Laojunshan granite forms a multi-phase pluton, defined by LA-MC-ICPMS/SHRIMP U-Pb dating of zircon and petrologic characteristics as (i) a marginal medium- to coarse-grained granite (87.5-92.9 $\mathrm{Ma})$; (ii) an inner medium- to fine-grained granite (83.3-89.7 Ma); and (iii) a small stock of porphyritic granite $(75.9-86.9 \mathrm{Ma})[21,22,24]$. 


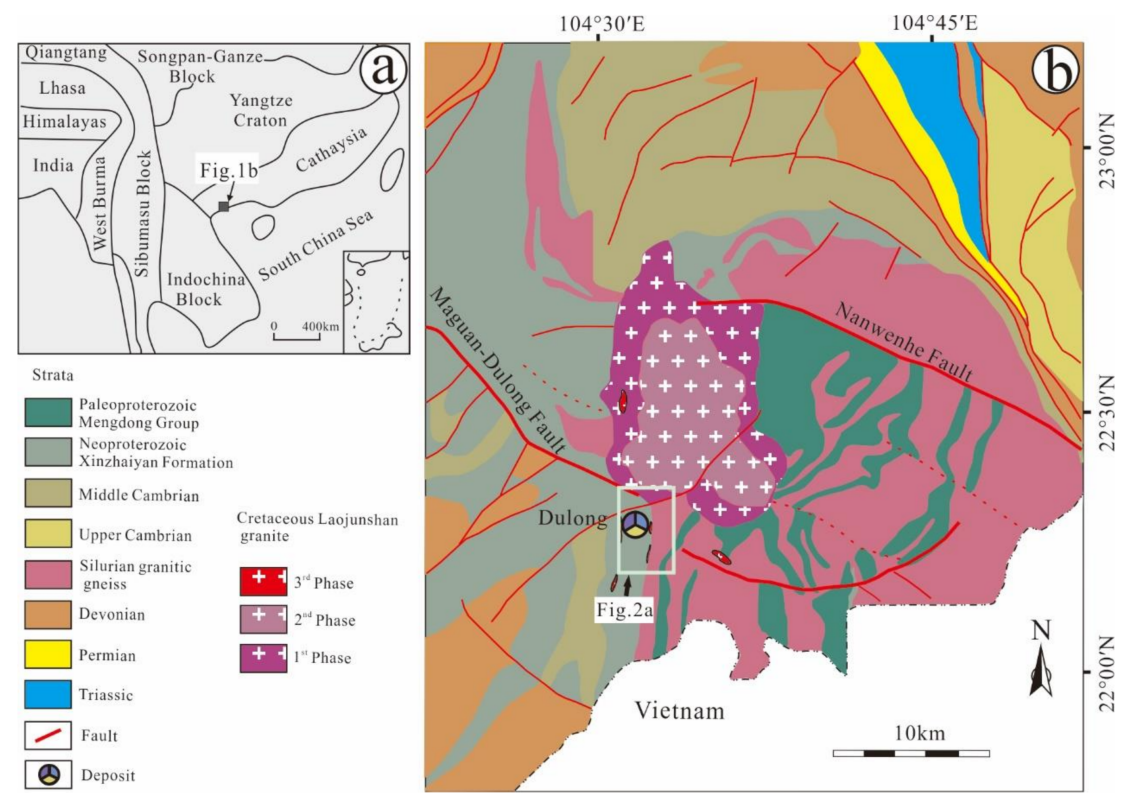

Figure 1. (a) Simplified structural map showing the location of the study area. (b) Geological sketch map of the Laojunshan Metamorphic Core Complex, Yunnan Province, China [22].

The Dulong Sn-Zn polymetallic deposit is located on the Southern margin of the Laojunshan granite (Figure 1b). The deposit (from North to South) contains the Tongiie, Manjiazhai, Lazizhai, Nandangchang, and Wukoudong ore sections (Figure 2a). At the middle of the Dulong mining area, exposed stratigraphy includes the Lower Cambrian Xinzhai Formation (main ore host) interlayered schist and marble. The Cambrian Tianpeng Formation in the Western portion of the Dulong mining area contains a suite of phyllite and marble, whereas the Paleoproterozoic Mengdong Group is locally exposed in the Southeastern portion of the Dulong mining area. Three sets of faults were identified at Dulong: North-south-trending ore-controlling faults $\left(\mathrm{F}_{0}, \mathrm{~F}_{1}\right.$ and $\left.\mathrm{F}_{2}\right)$ and North-westtrending strike-slip faults $\left(\mathrm{F}_{4}\right)$, and North-west- to North-south-trending Maguan-Dulong faults (Figure 2a). These faults control the local stratigraphic distribution. Granites in the Dulong mining area include mainly the Laojunshan granite (third phase), which occurs as quartz porphyry or granite porphyry dikes in the Southern end of the Laojunshan intrusive complex. Granites of phases 1 and 2 are intersected in drill holes at depth (Figure 2b). Geochemical data suggest that these granites are highly fractionated S-type granites, which originated from the same magma and derived from partial melting of the PaleoproterozoicMesoproterozoic pelitic basement rocks during lithospheric thinning and asthenospheric upwelling in an intra-arc rift or back-arc extension setting [21,22,24].
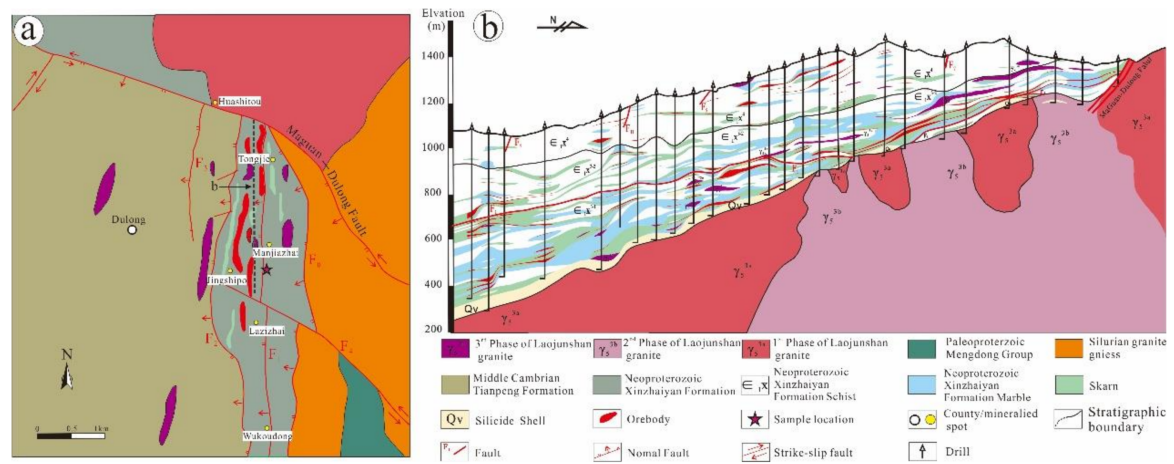

Figure 2. (a) Geological map of the Dulong Sn-Zn polymetallic skarn deposit [22]. (b) S-N cross section from the Lazizhai ore block $(\mathrm{S})$ to the Tongjie ore block $(\mathrm{N})$, modified after (geological data from Yunnan Hualian Mineral Exploration Co. Ltd., 2016; Qujing, China). 


\section{Samples and Analytical Methods}

As shown in field investigation, hand specimens, and in thin sections, three types of cassiterite were identified, including cassiterite-magnetite oxide \pm sulfide ore (Cst I), cassiterite-sulfide ore (Cst II) and cassiterite-quartz vein ore (Cst III). Three types of cassiterites in six samples from the Dulong district were collected from open pits of the Manjiazhai and Tongiie ore blocks (Figure 2a). Cst-I overgrows with magnetite (Figure 3a,d,e), Cst-II co-exists with sulfide (e.g., pyrrhotite, sphalerite, Figure $3 b, f, g$ ), Cst I-II mainly occurs within the proximal skarn in fault 1 in contact with the concealed granite. Cst-III occurs in quartz veins (Figure $3 c, h, i$ ) near porphyritic granite. All of the samples were made into sections, mounted in epoxy resin, and polished for analysis.
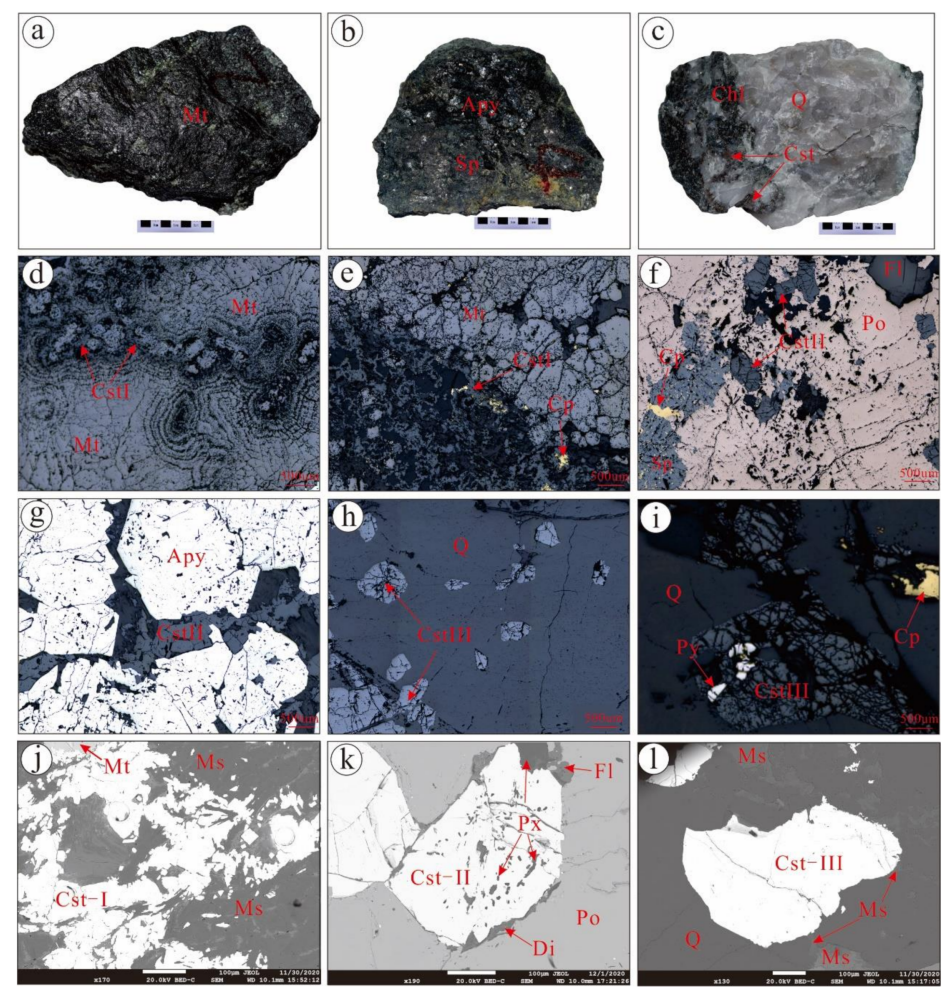

Figure 3. Photographs, photomicrographs, and BSE image of tin ores from the Dulong district. (a) Cassiterite-magnetite \pm sulfide ore. (b) Cassiterite-sulfide ore within the proximal skarn. (c) Cassiterite-quartz vein ore. (d) Photomicrographs of cassiterite-iron \pm sulfide (Cst I). (e) Cassiterite intergrowth with magnetite and chalcopyrite. (f) Photomicrographs of cassiterite-sulfide (Cst II). (g) Cassiterite intergrowth with pyrrhotite, sphalerite, and arsenopyrite. (h) Photomicrographs of cassiterite occurs in quartz vein. (i) Cassiterite in quartz vein intergrowth with chalcopyrite and pyrite. (j) BSE image of Cst I intergrowth with muscovite. (k) BSE image of Cst II intergrowth with pyroxene and diopside. (1) BSE image of Cst III overgrowth with muscovite and quartz. Abbreviations: $\mathrm{Cst}=$ cassiterite, $\mathrm{Mt}=$ magnetite, $\mathrm{Cp}=$ chalcopyrite, $\mathrm{Apy}=$ arsenopyrite, Po $=$ pyrrhotite, $\mathrm{Fl}=$ fluorite, $\mathrm{Px}=$ pyroxene, $\mathrm{Di}=$ diopside, $\mathrm{Py}=$ pyrite, $\mathrm{Q}=$ quartz, $\mathrm{Sp}=$ sphalerite, $\mathrm{Ms}=$ muscovite.

\subsection{Cathodoluminescence Imaging}

Before in-situ trace element and $\mathrm{U}-\mathrm{Pb}$ dating analysis, the polished sections were observed under scanning electron microscope (SEM) and optical microscope to characterize the texture of cassiterite. Backscattered electron (BSE) and cathodoluminescence (CL) images were taken using a JSM-7800F Field Emission SEM coupled with a cathodoluminescence detector at the State Key Laboratory of Ore Deposit Geochemistry (SKLODG), Institute of Geochemistry, Chinese Academy of Sciences (IGCAS) (Beijing, China). 


\subsection{LA-ICP-MS Cassiterite U-Pb Dating and Trace Elemental Analysis}

Cassiterite LA-ICP-MS trace element and $\mathrm{U}-\mathrm{Pb}$ dating analysis were conducted at LA laboratory of the SKLODG, IGCAS. The analytical system is composed of a GeoLas Pro 193-nm ArF excimer laser ablation system and an Agilent 7500 × ICP-MS instrument. Helium was used as a carrier gas and was mixed with argon via a T-connector before entering the ICP-MS. Cassiterite trace element and $\mathrm{U}-\mathrm{Pb}$ analyses were conducted separately with a laser energy density of $8 \mathrm{~J} / \mathrm{cm}^{2}$, a repetition of $7 \mathrm{~Hz}$, and a spot size of $60 \mu \mathrm{m}$. The cassiterite standard (AY-4) was used as an external standard for cassiterite U-Pb dating and returned the weighted mean ${ }^{206} \mathrm{~Pb} /{ }^{238} \mathrm{U}$ age of $158.1 \pm 1.6 \mathrm{Ma}$, which is identical to the recommended ID-TIMS age of $158.2 \pm 0.4 \mathrm{Ma}$ [12]. Standard reference material (NIST 612) was used for cassiterite trace element calculation using Sn as the internal standard. The detailed analysis process is as described by $[29,30]$. Data reduction was carried out by the ICPMSDataCal program [31,32].

\section{Results}

\subsection{Cassiterite $\mathrm{U}-\mathrm{Pb}$ Age}

Based on photomicrographs and CL images, $\mathrm{U}-\mathrm{Pb}$ isotopic analyses were performed on domains where cracks are rare. Three types of cassiterite (Cst I, Cst II, and Cst III) were used for $\mathrm{U}-\mathrm{Pb}$ dating. However, due to the cassiterite, particles are too small (commonly $<60 \mathrm{um}$ ) (Figure $4 \mathrm{a}$ ), and U-Pb dating for Cst I failed. LA-ICP-MS cassiterite U-Pb isotopic analyses were performed on two cassiterite samples (Cst-II: DL18-153 and Cst-III: DL18122). Representative CL images of the separated cassiterite are given in Figure 4. The LAICP-MS analytical results are summarized in Table 1 and plotted in Figure 5.

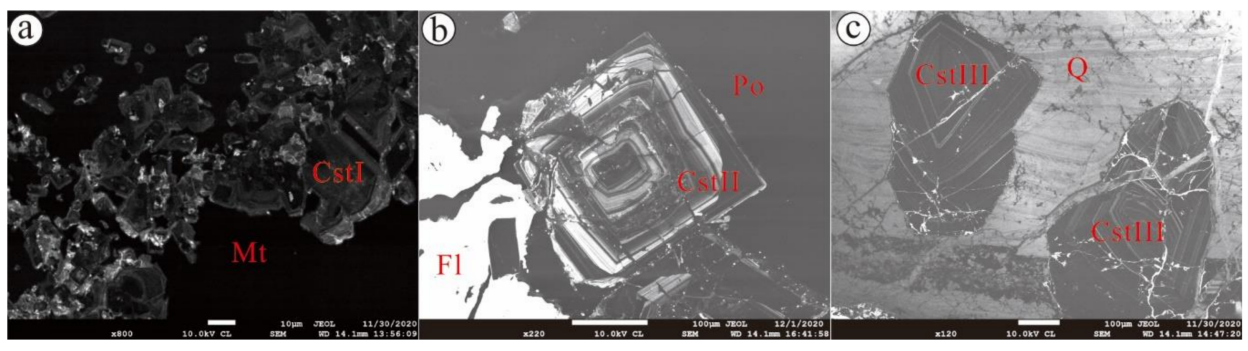

Figure 4. Cathodoluminescence images of three types of cassiterite in the Dulong district. (a) Cst I. (b) Cst II. (c) Cst III. Abbreviations: Cst = cassiterite, $\mathrm{Mt}=$ magnetite, $\mathrm{Po}=$ pyrrhotite, $\mathrm{Fl}=$ fluorite, $\mathrm{Q}=$ quartz.

Twenty-eight spot analyses were carried out for sample DL18-153 (Table 1) from $F_{1}$ proximal skarn. The cassiterite grains have low Th contents and countable U. The composition of the 28 ablated spots on the cassiterite grains varies from 0.01 to $1.50 \mathrm{ppm}$ total $\mathrm{Pb},<0.34 \mathrm{ppm} \mathrm{Th}$, and 0.71 to $6.93 \mathrm{ppm} \mathrm{U}$, respectively. The analytical spots gave a Tera-Wasserburg U-Pb lower intercept age of $88.5 \pm 2.1 \mathrm{Ma}(2 \sigma, n=28$, MSWD $=0.96)$ (Figure 5a). The analyses yielded a weighted mean ${ }^{206} \mathrm{~Pb} /{ }^{238} \mathrm{U}$ age of $87.1 \pm 1.6 \mathrm{Ma}(2 \sigma$, $n=18, \mathrm{MSWD}=1.3$ ) (Figure $5 \mathrm{~b}$ ) after ${ }^{207} \mathrm{~Pb}$-based correction, which agrees well with the Tera-Wasserburg $\mathrm{U}-\mathrm{Pb}$ lower intercept age within error. This indicates that the age can accurately represent the crystallization age of the cassiterite in the skarn.

Twenty spot analyses were carried out for sample DL18-123 from the quartz vein (Table 1). The cassiterite grains have countable $U$ and low Th contents. The composition of the 20 ablated spots on the cassiterite grains varies from 0.01 to $0.2 \mathrm{ppm}$ total $\mathrm{Pb},<0.04 \mathrm{ppm}$ $\mathrm{Th}$, and 0.15-1.67 ppm U, respectively. The analytical spots gave a Tera-Wasserburg U-Pb lower intercept age of $82.1 \pm 6.3 \mathrm{Ma}(2 \sigma, n=20$, MSWD =1.6) (Figure 5c). The analyses yielded a weighted mean ${ }^{206} \mathrm{~Pb} /{ }^{238} \mathrm{U}$ age of $77.7 \pm 4.4 \mathrm{Ma}(2 \sigma, n=8, \mathrm{MSWD}=1.3)$ (Figure $5 \mathrm{~d}$ ) after ${ }^{207} \mathrm{~Pb}$-based correction, which agrees well with the Tera-Wasserburg $\mathrm{U}-\mathrm{Pb}$ lower intercept age within error. This indicates that the age can accurately represent the crystallization age of the cassiterite in the quartz vein. 
Table 1. LA-ICP-MS U-Pb dating results of cassiterite in the Dulong Sn-Zn-In deposit.

\begin{tabular}{|c|c|c|c|c|c|c|c|c|c|c|c|c|c|}
\hline \multirow{2}{*}{$\begin{array}{c}\text { Sample } \\
\text { Types }\end{array}$} & \multirow{2}{*}{ Spots } & \multirow{2}{*}{$\begin{array}{l}\text { Common } \\
\mathrm{Pb}(\mathrm{ppm})\end{array}$} & \multirow{2}{*}{$\begin{array}{c}\text { Total Pb } \\
\text { (ppm) }\end{array}$} & \multirow{2}{*}{$\begin{array}{l}{ }^{232} \mathrm{Th} \\
\text { (ppm) }\end{array}$} & \multirow{2}{*}{$\begin{array}{c}{ }^{238} \mathrm{U} \\
\text { (ppm) }\end{array}$} & \multirow[b]{2}{*}{${ }^{207} \mathrm{~Pb} /{ }^{206} \mathrm{~Pb}$} & \multirow[b]{2}{*}{$1 \sigma$} & \multicolumn{2}{|c|}{ Isotopic Ratios } & \multirow[b]{2}{*}{${ }^{206} \mathrm{~Pb} /{ }^{238} \mathrm{U}$} & \multirow[b]{2}{*}{$1 \sigma$} & \multicolumn{2}{|c|}{ Isotopic Ages (Ma } \\
\hline & & & & & & & & ${ }^{207} \mathrm{~Pb} /{ }^{235} \mathrm{U}$ & $1 \sigma$ & & & ${ }^{206} \mathrm{~Pb} /{ }^{238} \mathrm{U}$ & $1 \sigma$ \\
\hline \multicolumn{14}{|c|}{ Cassiterite-sulfide ore (Cst II) } \\
\hline & DL18-153-1 & 1.94 & 1.50 & 0.15 & 4.79 & 0.76496 & 0.05783 & 9.94093 & 0.81685 & 0.09252 & 0.00383 & 570.5 & 22.6 \\
\hline & DL18-153-3 & 0.27 & 0.56 & 0.21 & 4.68 & 0.64264 & 0.04305 & 3.68992 & 0.23391 & 0.04228 & 0.00111 & 267.0 & 6.9 \\
\hline & DL18-153-4 & - & 0.48 & 0.34 & 4.51 & 0.63222 & 0.06081 & 3.40888 & 0.27759 & 0.04027 & 0.00157 & 254.5 & 9.7 \\
\hline & DL18-153-5 & 0.64 & 0.36 & 0.04 & 3.88 & 0.61718 & 0.05941 & 3.04216 & 0.27287 & 0.03619 & 0.00128 & 229.1 & 7.9 \\
\hline & DL18-153-6 & 0.33 & 0.38 & 0.03 & 5.72 & 0.46023 & 0.03693 & 1.76507 & 0.13231 & 0.02827 & 0.00101 & 179.7 & 6.4 \\
\hline & DL18-153-8 & 0.12 & 0.22 & 0.23 & 4.25 & 0.44295 & 0.04637 & 1.38334 & 0.13034 & 0.02339 & 0.00074 & 149.1 & 4.7 \\
\hline & DL18-153-9 & 0.05 & 0.10 & 0.05 & 3.24 & 0.32858 & 0.03885 & 0.80266 & 0.08402 & 0.01953 & 0.00081 & 124.7 & 5.1 \\
\hline & DL18-153-10 & 0.58 & 0.14 & 0.02 & 4.68 & 0.26312 & 0.02798 & 0.63991 & 0.05689 & 0.01854 & 0.00071 & 118.4 & 4.5 \\
\hline & DL18-153-11 & 0.14 & 0.08 & 0.11 & 2.84 & 0.27731 & 0.03630 & 0.56330 & 0.05742 & 0.01824 & 0.00101 & 116.5 & 6.4 \\
\hline & DL18-153-12 & 0.39 & 0.16 & 0.12 & 6.04 & 0.22185 & 0.02101 & 0.51469 & 0.04456 & 0.01766 & 0.00063 & 112.8 & 4.0 \\
\hline & DL18-153-13 & - & 0.14 & 0.07 & 5.71 & 0.24848 & 0.02185 & 0.52537 & 0.03870 & 0.01693 & 0.00055 & 108.2 & 3.5 \\
\hline & DL18-153-14 & 0.02 & 0.02 & 0.02 & 1.01 & 0.33968 & 0.06501 & 0.63821 & 0.10233 & 0.01674 & 0.00120 & 107.0 & 7.6 \\
\hline & DL18-153-15 & 0.12 & 0.12 & 0.10 & 5.19 & 0.15675 & 0.01964 & 0.35159 & 0.04125 & 0.01648 & 0.00060 & 105.4 & 3.8 \\
\hline & DL18-153-16 & 0.51 & 0.08 & 0.01 & 2.98 & 0.25403 & 0.03346 & 0.51395 & 0.05781 & 0.01642 & 0.00073 & 105.0 & 4.7 \\
\hline & DL18-153-18 & - & 0.10 & 0.03 & 4.00 & 0.23632 & 0.03035 & 0.47869 & 0.05260 & 0.01605 & 0.00073 & 102.7 & 4.6 \\
\hline & DL18-153-19 & 0.01 & 0.01 & 0.01 & 0.71 & 0.27260 & 0.05929 & 0.54487 & 0.08337 & 0.01575 & 0.00136 & 100.8 & 8.6 \\
\hline & DL18-153-20 & - & 0.11 & 0.01 & 5.40 & 0.18607 & 0.03307 & 0.34811 & 0.05863 & 0.01560 & 0.00056 & 99.8 & 3.6 \\
\hline & DL18-153-21 & 0.20 & 0.08 & 0.06 & 4.14 & 0.17853 & 0.01889 & 0.35007 & 0.03227 & 0.01546 & 0.00057 & 98.9 & 3.6 \\
\hline & DL18-153-22 & 0.27 & 0.09 & 0.02 & 5.08 & 0.10905 & 0.01411 & 0.21539 & 0.02693 & 0.01512 & 0.00051 & 96.7 & 3.3 \\
\hline & DL18-153-23 & 0.30 & 0.07 & 0.01 & 3.77 & 0.10084 & 0.01537 & 0.20033 & 0.02924 & 0.01510 & 0.00065 & 96.6 & 4.1 \\
\hline & DL18-153-24 & 0.08 & 0.10 & - & 5.90 & 0.16070 & 0.05001 & 0.29892 & 0.10809 & 0.01484 & 0.00062 & 94.9 & 3.9 \\
\hline & DL18-153-25 & - & 0.08 & - & 4.81 & 0.12056 & 0.01605 & 0.22115 & 0.02671 & 0.01463 & 0.00060 & 93.6 & 3.8 \\
\hline & DL18-153-26 & - & 0.10 & 0.01 & 6.93 & 0.06756 & 0.00892 & 0.13140 & 0.01648 & 0.01454 & 0.00043 & 93.0 & 2.7 \\
\hline & DL18-153-27 & - & 0.08 & 0.04 & 5.04 & 0.11404 & 0.01839 & 0.19321 & 0.02394 & 0.01450 & 0.00066 & 92.8 & 4.2 \\
\hline & DL18-153-28 & 0.25 & 0.10 & - & 6.10 & 0.06714 & 0.00946 & 0.12492 & 0.01465 & 0.01417 & 0.00055 & 90.7 & 3.5 \\
\hline \multicolumn{14}{|c|}{ Cassiterite-quartz vein ore (Cst III) } \\
\hline & DL18-23-1 & 0.25 & 0.08 & 0.02 & 0.29 & 0.82174 & 0.10892 & 8.02528 & 0.76264 & 0.07127 & 0.00597 & 443.8 & 35.9 \\
\hline & DL18-23-2 & - & 0.01 & - & 0.12 & 0.33867 & 0.07385 & 5.49101 & 0.88852 & 0.06226 & 0.00969 & 389.4 & 58.8 \\
\hline & DL18-23-3 & 0.22 & 0.09 & 0.03 & 0.48 & 0.88755 & 0.11209 & 6.09920 & 0.55820 & 0.06021 & 0.00338 & 376.9 & 20.5 \\
\hline & DL18-23-4 & 0.34 & 0.02 & 0.00 & 0.15 & 0.43087 & 0.07936 & 5.28741 & 0.56324 & 0.05336 & 0.00503 & 335.1 & 30.8 \\
\hline & DL18-23-5 & 0.25 & 0.05 & 0.02 & 0.37 & 0.85089 & 0.14860 & 3.70567 & 0.35982 & 0.04601 & 0.00325 & 290.0 & 20.0 \\
\hline
\end{tabular}


Table 1. Cont

\begin{tabular}{|c|c|c|c|c|c|c|c|c|c|c|c|c|c|}
\hline \multirow{2}{*}{$\begin{array}{l}\text { Sample } \\
\text { Types }\end{array}$} & \multirow{2}{*}{ Spots } & \multirow{2}{*}{$\begin{array}{l}\text { Common } \\
\mathrm{Pb}(\mathrm{ppm})\end{array}$} & \multirow{2}{*}{$\begin{array}{c}\text { Total Pb } \\
\text { (ppm) }\end{array}$} & \multirow{2}{*}{$\begin{array}{l}{ }^{232} \mathrm{Th} \\
\text { (ppm) }\end{array}$} & \multirow{2}{*}{$\begin{array}{c}{ }^{238} \mathrm{U} \\
(\mathrm{ppm})\end{array}$} & \multirow[b]{2}{*}{${ }^{207} \mathrm{~Pb} /{ }^{206} \mathrm{~Pb}$} & \multirow[b]{2}{*}{$1 \sigma$} & \multicolumn{2}{|c|}{ Isotopic Ratios } & \multirow[b]{2}{*}{${ }^{206} \mathrm{~Pb} /{ }^{238} \mathrm{U}$} & \multirow[b]{2}{*}{$1 \sigma$} & \multicolumn{2}{|c|}{ Isotopic Ages (Ma) } \\
\hline & & & & & & & & ${ }^{207} \mathrm{~Pb} /{ }^{235} \mathrm{U}$ & $1 \sigma$ & & & ${ }^{206} \mathrm{~Pb} /{ }^{238} \mathrm{U}$ & $1 \sigma$ \\
\hline & DL18-23-6 & 0.12 & 0.03 & 0.02 & 0.23 & 0.84975 & 0.16550 & 4.93755 & 0.55685 & 0.04601 & 0.00426 & 290.0 & 26.3 \\
\hline & DL18-23-7 & 0.25 & 0.20 & 0.04 & 1.67 & 0.69616 & 0.06205 & 3.40158 & 0.21752 & 0.04071 & 0.00159 & 257.2 & 9.9 \\
\hline & DL18-23-9 & 0.14 & 0.03 & 0.01 & 0.32 & 0.53889 & 0.10979 & 2.28925 & 0.32303 & 0.03182 & 0.00241 & 201.9 & 15.1 \\
\hline & DL18-23-10 & 0.44 & 0.04 & 0.02 & 0.39 & 0.47061 & 0.07025 & 1.98190 & 0.23786 & 0.03131 & 0.00237 & 198.7 & 14.8 \\
\hline & DL18-23-11 & - & 0.07 & 0.02 & 0.89 & 0.62347 & 0.07884 & 2.43991 & 0.32825 & 0.03122 & 0.00233 & 198.2 & 14.6 \\
\hline & DL18-23-12 & 0.41 & 0.02 & 0.01 & 0.35 & 0.18949 & 0.06204 & 0.75608 & 0.13889 & 0.02032 & 0.00300 & 129.7 & 18.9 \\
\hline & DL18-23-14 & - & 0.05 & 0.03 & 0.87 & 0.56242 & 0.10075 & 1.13504 & 0.11522 & 0.01960 & 0.00140 & 125.1 & 8.9 \\
\hline & DL18-23-15 & - & 0.02 & 0.01 & 0.44 & 0.20230 & 0.04294 & 0.89495 & 0.13713 & 0.01836 & 0.00140 & 117.3 & 8.9 \\
\hline & DL18-23-16 & 0.20 & 0.03 & 0.02 & 1.06 & 0.32221 & 0.09983 & 0.57415 & 0.09827 & 0.01761 & 0.00128 & 112.5 & 8.1 \\
\hline & DL18-23-17 & - & 0.01 & - & 0.33 & 0.14783 & 0.05881 & 0.74420 & 0.22048 & 0.01687 & 0.00207 & 107.9 & 13.1 \\
\hline & DL18-23-18 & 0.12 & 0.03 & - & 1.18 & 0.32308 & 0.08333 & 0.53180 & 0.07505 & 0.01629 & 0.00105 & 104.2 & 6.7 \\
\hline & DL18-23-19 & 0.20 & 0.02 & - & 0.74 & 0.13434 & 0.04707 & 0.28979 & 0.05965 & 0.01478 & 0.00105 & 94.6 & 6.7 \\
\hline & DL18-23-20 & 0.67 & 0.02 & - & 0.19 & 0.00987 & 0.00271 & 0.11606 & 0.02068 & 0.01244 & 0.00146 & 79.7 & 9.3 \\
\hline
\end{tabular}



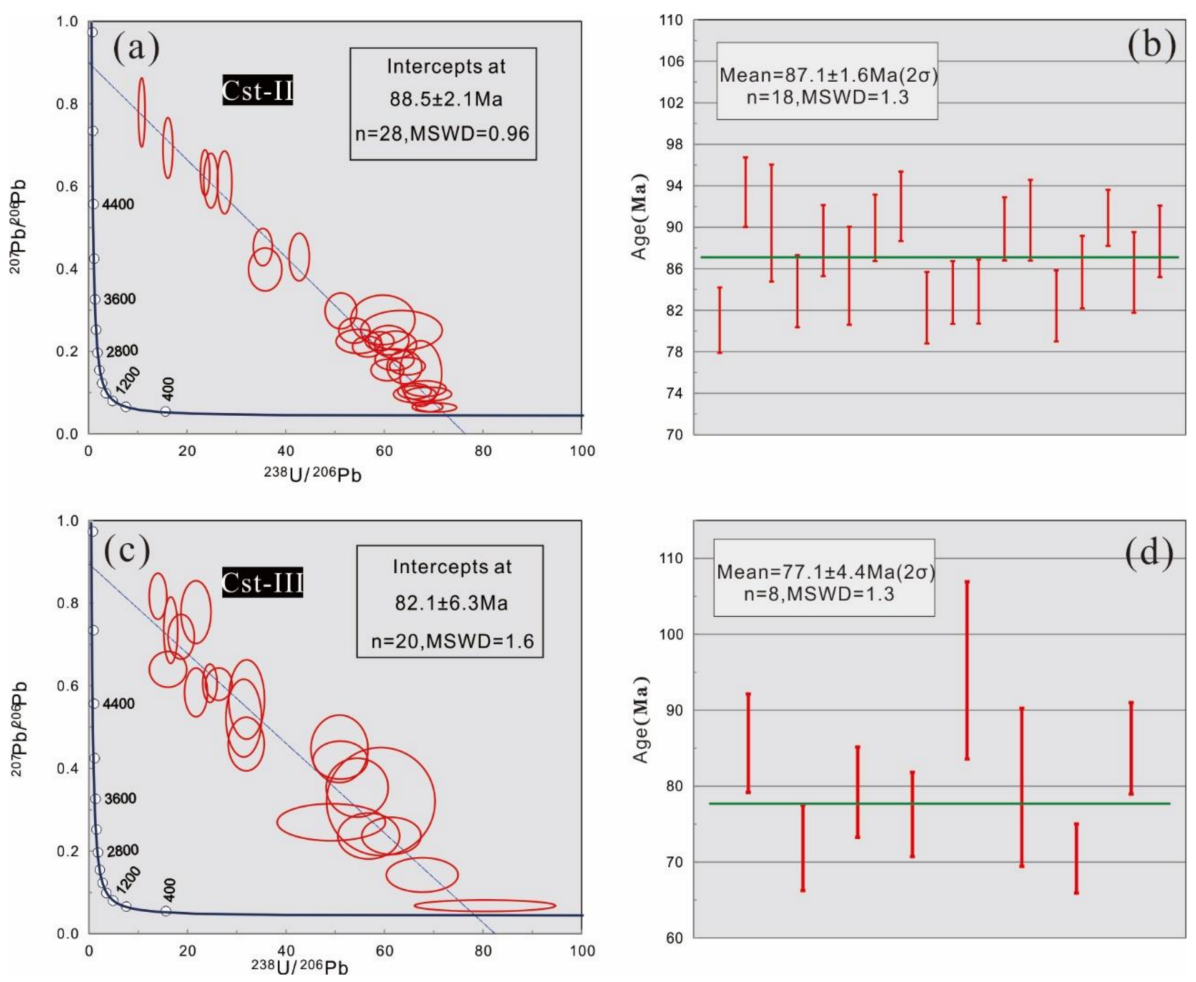

Figure 5. Tera-Wasserburg $\mathrm{U}-\mathrm{Pb}$ concordia plots and weighted mean diagram of ${ }^{206} \mathrm{~Pb} /{ }^{238} \mathrm{U}$ age by ${ }^{207} \mathrm{~Pb}$-based correction for cassiterite from the Dulong Sn-Zn-In deposit. (a,b) Cassiterite-sulfide ore (Cst II), sample DL18-153. (c,d) Cassiterite-quartz vein ore (Cst III), sample DL18-123.

\subsection{Compositions of Cassiterite}

In-situ LA-ICPMS trace element data sets in three types of cassiterite (Cst I-III) are show in Table S1. Several trace elements in cassiterite from Dulong are relatively high, such as $\mathrm{Al}$ (<bld-1113 ppm), Ca (<bld-134 ppm), Ti (0.26-2007 ppm), V (0.02-410 ppm), Mn (<bld-200 ppm), Fe (218-14457 ppm), Ga (<bld-98 ppm), Zr (<bld-114 ppm), and W (<bld-4257 ppm). Trace elements such as $\mathrm{Nb}$ (<bld-22 ppm), Ta (<bld-0.31 ppm), and Hf $(<$ bld $-2.60 \mathrm{ppm}$ ) are relatively low in cassiterite grains. The $\mathrm{U}$ concentrations are commonly below $15 \mathrm{ppm}$. The concentrations of other trace elements are very low (e.g., $\leq 2 \mathrm{ppm} \mathrm{Cu}$, $\leq 10 \mathrm{ppm} \mathrm{Ge}$, and $\leq 2 \mathrm{ppm} \mathrm{Sr}$ ). Interestingly, there are clear positive correlations between $\mathrm{Nb}$ and $\mathrm{Ta}, \mathrm{Zr}$ and $\mathrm{Hf}, \mathrm{V}$ and $\mathrm{Sc}, \mathrm{Fe}$ and $\mathrm{Ga}$, as shown in Figure 6.

Comparing the three types of cassiterite: Cst I have higher concentrations of $\mathrm{Mn}, \mathrm{Fe}$, $\mathrm{Ga}, \mathrm{As}, \mathrm{Rb}$ and $\mathrm{W}$; Cst II has higher concentrations of Ti, V and $\mathrm{Zr}$ and Cst III has higher concentrations of $\mathrm{Fe}$ and $\mathrm{Sb}$. 

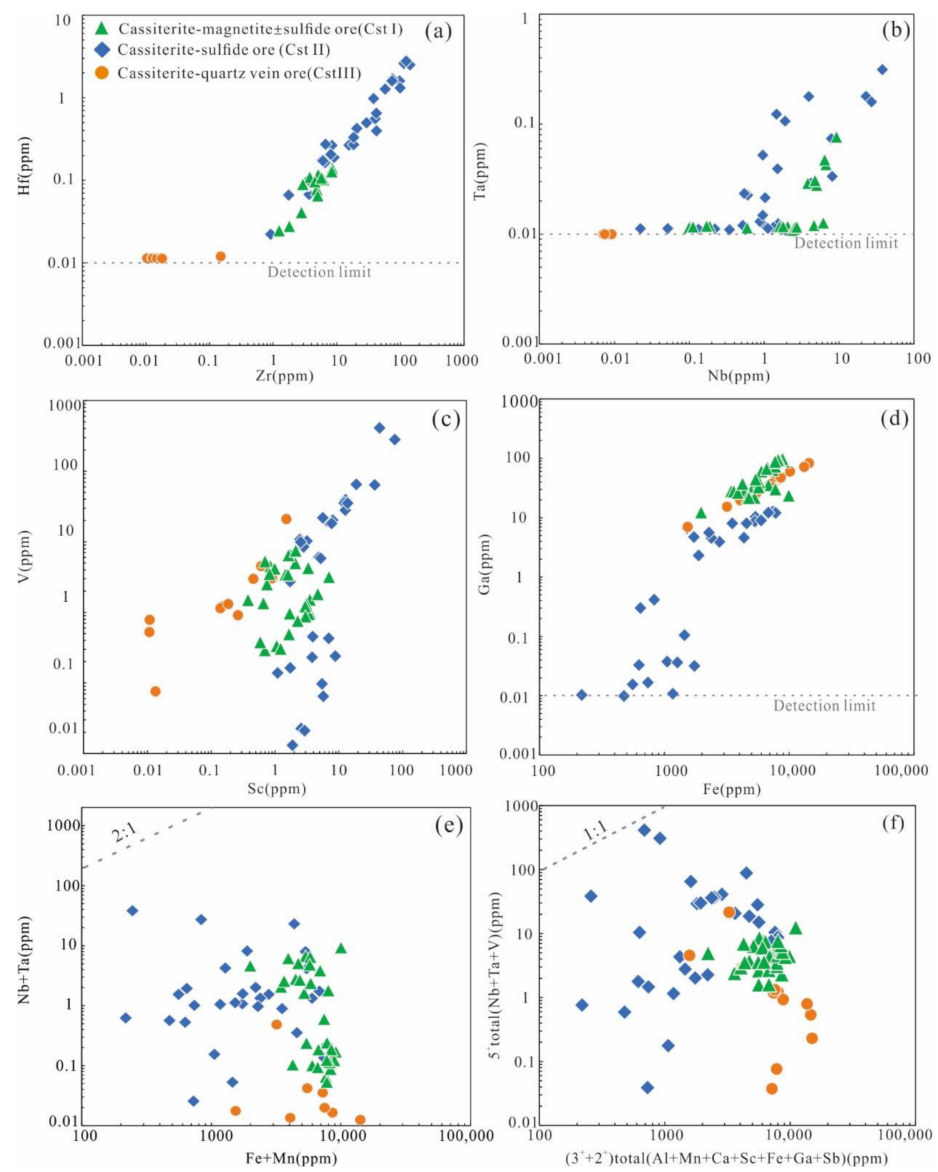

Figure 6. Binary plots of (a) Zr vs. Hf, (b) $\mathrm{Nb}$ vs. Ta, (c) Sc vs. V, (d) Fe vs. Ga, (e) Fe $+\mathrm{Mn}$ vs. $\mathrm{Nb}+$ $\mathrm{Ta}$, (f) $\mathrm{Al}+\mathrm{Mn}+\mathrm{Ca}+\mathrm{Sc}+\mathrm{Ga}+\mathrm{Sb}$ vs. $\mathrm{Nb}+\mathrm{Ta}+\mathrm{V}$ in cassiterite samples from the Dulong district.

\section{Discussion}

\subsection{Mechanism of Sn Precipitation}

Sn precipitation from hydrothermal fluids can be caused by various mechanisms [2] including fluid boiling [33], hydrothermal fluid mixing [34,35], and wall-rock interaction [36]. Sn is dominantly transported as $\mathrm{Sn}^{2+}-\mathrm{Cl}$ complexes in the hydrothermal solution although $\mathrm{Sn}$ in cassiterite is present as $\mathrm{Sn}^{4+}$. Sn solubility may be controlled by the reaction equilibrium described by reaction (1) $[2,10,37]$.

$$
\left[\mathrm{Sn}(\mathrm{II}) \mathrm{Cl}_{\mathrm{x}}\right]^{2-\mathrm{x}}+2 \mathrm{H}_{2} \mathrm{O} \leftrightarrow \mathrm{Sn}(\mathrm{IV}) \mathrm{O}_{2}+2 \mathrm{H}^{+}+\mathrm{XCl}^{-}+\mathrm{H}_{2}
$$

It is suggested that cassiterite precipitation from a Sn-rich fluid is driven by acid neutralization, oxidation $\left(\mathrm{H}_{2}\right.$ loss), or decreasing salinity ([2] and references therein). Boiling or two-phase fluid separation of $\mathrm{Sn}$-rich fluids can lead to cassiterite precipitation due to preferential removal of $\mathrm{HCl}^{\text {(gas) }}$ [3] and/or through loss $\mathrm{H}_{2} . \mathrm{H}_{2}$ is consumed in the reaction between aluminosilicate rocks and the mineralizing fluids [2]. As opposed to simple boiling, wall-rock reaction is an effective Sn precipitation mechanism [2], Thus, acid-consuming reactions could help balance the acidity liberated during precipitation of cassiterite from mineralizing fluids.

In the Dulong district, cassiterite are closely associated with muscovite in massive magnetite (Figure $3 \mathrm{~d}-\mathrm{e}, \mathrm{j}$ ), quartz vein (Figure $3 \mathrm{~h}-\mathrm{i}, \mathrm{l}$ ) and / or pyroxene in sulfides (Figure $3 \mathrm{f}-\mathrm{g}, \mathrm{k}$ ). This phenomenon possibly implies the interaction of the Sn mineralizing fluid with biotiterich wall-rock, forming muscovite and quartz according to reaction (2) [10,38], and Sn mineralizing fluid with pyroxene-rich wall-rock, leading to diopside precipitation by the following reaction (3) [38]. If correct, the removal of $\mathrm{HCl}$ according to reaction (2-3) from 
Sn mineralizing fluid may be one of the mechanisms that enhance cassiterite $\mathrm{Sn}$ (IV)O2 precipitation by reaction (1).

$$
\begin{gathered}
3 \mathrm{KFe}_{3} \mathrm{AlSi}_{3} \mathrm{O} 10(\mathrm{OH})_{2} \text { (biotite) } \\
+20 \mathrm{HCl} \leftrightarrow \mathrm{KAl}_{3} \mathrm{Si}_{3} \mathrm{O}_{10} \text { (muscovite) }+6 \mathrm{SiO}_{2} \text { (quartz) } \\
+9 \mathrm{FeCl}_{2}+2 \mathrm{KCl}+12 \mathrm{H}_{2} \mathrm{O} \\
\mathrm{FeMgSi}_{2} \mathrm{O}_{6} \text { (pyroxene) }+2 \mathrm{HCl} \leftrightarrow \mathrm{MgSiO}_{3} \text { (diopside) }+\mathrm{SiO}_{2} \text { (quartz) }+\mathrm{FeCl}_{2}+\mathrm{H}_{2} \mathrm{O}
\end{gathered}
$$

It is suggested that Sn-precipitation in the Dulong Sn-Zn-In polymetallic deposit is likely to have been driven by acid neutralization reactions considering cassiterite's close association with muscovite and diopside. Unfortunately, these data could not be used to constrain the processes involved in fluid evolution (e.g., boiling, vapor separation, meteoric water mixing, etc.) and ore-forming processes, which are both complex and beyond the scope of our study.

\subsection{Trace Elements Substitution in Cassiterite}

The cassiterite structure is similar to that of rutile, with oxygen coordination with $\mathrm{Sn}^{4+}$ in six-fold symmetry. Because of its atomic structure, cassiterite can incorporate a wide range of trace elements to substitute for $\mathrm{Sn}^{4+}[39,40]$, especially by ions with similar or closer ionic radius to $\mathrm{Sn}^{4+}(0.69 \AA)$ such as $\mathrm{Mn}^{2+}(0.67 \AA), \mathrm{Fe}^{2+}(0.61$ or $0.78 \AA), \mathrm{Fe}^{3+}(0.645 \AA), \mathrm{Ta}^{4+}$ $(0.68 \AA), \mathrm{Ta}^{5+}(0.64 \AA)$ and $\mathrm{Nb}^{5+}(0.64 \AA)$ (ionic radii after [41]). Other elements including $\mathrm{Sc}^{3+}(0.745 \AA), \mathrm{V}^{3+}(0.64 \AA), \mathrm{Sb}^{3+}(0.76 \AA), \mathrm{Al}^{3+}(0.535 \AA), \mathrm{Ga}^{3+}(0.62 \AA), \mathrm{Ti}^{4+}(0.605 \AA)$, $\mathrm{Zr}^{4+}(0.72 \AA), \mathrm{Hf}^{4+}(0.71 \AA), \mathrm{W}^{4+}(0.66 \AA), \mathrm{U}^{4+}(0.89 \AA)$ and $\mathrm{V}^{5+}(0.54 \AA)$ are also likely to substitute into cassiterite considering their ionic charge, coordination, and radius $[6,10,41]$. Several mechanisms have been proposed for the substitution of trace elements in cassiterite. Quadrivalent elements (e.g., $\mathrm{Zr}^{4+}, \mathrm{Hf}^{4+}, \mathrm{Ti}^{4+}, \mathrm{W}^{4+}$ and $\mathrm{U}^{4+}$ ) can directly substitute for $\mathrm{Sn}^{4+}$ in cassiterite [6]. Zr-Hf and $\mathrm{Nb}-\mathrm{Ta}$ have similar ionic radii and ionic charge, and thus display similar geochemical behavior, so $\mathrm{Zr}-\mathrm{Hf}$ maintain a relatively constant ratio near the chondrite $\mathrm{Zr} / \mathrm{Hf}$ ratio of 35 to 40 in most geological systems [6,42], and $\mathrm{Nb}$-Ta maintain relativity uniform $\mathrm{Nb} / \mathrm{Ta}$ values of 10 to 20 in terrestrial reservoirs [10,43]. This may be the main reason for the positive correlation between $\mathrm{Zr}$ and $\mathrm{Hf}$ as well as for $\mathrm{Nb}$ and $\mathrm{Ta}$ in the Dulong cassiterite samples (Figure 7a,b). The geochemical behaviors of V, Sc, and Ga with regard to partitioning between fluid and cassiterite are poorly understood [6]. In the Dulong cassiterite samples, there is a clear positive correlation between $\mathrm{V}$ and $\mathrm{Sc}$ and between Fe and $\mathrm{Ga}$ (Figure $6 \mathrm{c}, \mathrm{d})$. Because Sc has only one valence state (3+), the positive correlation between $\mathrm{V}$ and $\mathrm{Sc}$ in cassiterite leads to a charge-balanced coupled substitution of $\mathrm{Sc}^{3+}+\mathrm{V}^{5+}=2 \mathrm{Sn}^{4+}$. Because both $\mathrm{Fe}^{3+}(0.645 \AA)$ and $\mathrm{Ga}^{3+}(0.62 \AA)$ have very similar ionic radii [41], their close correlation may indicate that Fe and $\mathrm{Ga}$ are trivalent cations in the Dulong cassiterite samples [6]. Studies on the geochemistry of cassiterite indicated that coupled substitution mechanisms of trace elements in cassiterite are another mechanism to preserve electroneutrality as shown by reaction (4) $[8,44]$ and (5) [10].

$$
\begin{gathered}
2(\mathrm{Nb}, \mathrm{Ta})^{5+}+(\mathrm{Fe}, \mathrm{Mn})^{2+} \leftrightarrow 3(\mathrm{Ti}, \mathrm{Sn})^{4+} \\
(2-\mathrm{n})(\mathrm{Nb}, \mathrm{Ta}, \mathrm{V})^{5+}+\left[(1-\mathrm{n})(\mathrm{Fe}, \mathrm{Mn}, \mathrm{Ca}, \mathrm{Mg})^{2+}+\mathrm{n}(\mathrm{Al}, \mathrm{Sc}, \mathrm{Fe})^{3+}\right] \leftrightarrow(3-n) \mathrm{Sn}^{4+}
\end{gathered}
$$

where $0 \leq \mathrm{n} \leq 1$.

If such a mechanism dominates for cassiterite in the Dulong district, similar to reaction (4) or (5), there should be a 2:1 balance between total divalent ( $\mathrm{Fe}, \mathrm{Mn}$ ) and total pentavalent $(\mathrm{Nb}, \mathrm{Ta})$ cations or positive correlation between total pentavalent elements $(\mathrm{Nb}, \mathrm{Ta}, \mathrm{V})$ and a total of both divalent $(\mathrm{Mn}, \mathrm{Ca})$ and trivalent elements $(\mathrm{Al}, \mathrm{Sc}, \mathrm{Fe}, \mathrm{Ga}$, $\mathrm{Sb}$ ) substituting for $\mathrm{Sn}$ in the cassiterites. However, we observe a significant excess in trivalent and divalent cations in almost all cases (Figure 6e,f), which means that there needs to be an additional mechanism to incorporate trivalent and divalent cations (mostly $\mathrm{Fe}^{3+}$ ). Hence, it is suggested that the substitution is dominated by the coupled substitution: $\mathrm{Fe}^{3+}+\mathrm{OH}^{-}=\mathrm{Sn}^{4+}+\mathrm{O}^{2-}$, similar to the results proposed by previous studies $[8,45,46]$. 
CL is a powerful tool in revealing the complicated microtextures of minerals that are otherwise not obvious [6,47-50]. With regard to CL images, three types of cassiterite were identified in the Dulong Sn-Zn-In polymetallic deposit. Each type displays distinctive CL textures and trace element patterns. The CL intensity of Cst I-II cassiterites are much higher than Cst III cassiterites (Figure 4). Previous studies showed that Al, Ti, and W are the luminescence activators of cassiterite, but that Fe quenches the luminescence $[51,52]$. Average contents of $\mathrm{Al}(\sim 358 \mathrm{ppm}), \mathrm{W}(\sim 1912 \mathrm{ppm})$ in Cst I and Ti ( 374 ppm) in Cst II are slightly higher than those in Cst III ( 163.7 ppm Al; 17.4 ppm Ti; 402 ppm W), however, Cst III has higher contents of Fe $(\sim 7960$ ppm) than Cst I ( 6297 ppm) and Cst II ( 2586 ppm). These activator elements should have generated more intense luminescence in Cst-I and Cst II. In contrast, Cst III is nonluminescent.

\subsection{Genesis of Cassiterite}

Studies of the geochemical composition of cassiterite indicated that some of the elements in cassiterite can be applied as indicators of formation environment and the source fluid composition [8,39,40,53]. Most Sn-bearing deposits in the world are genetically and spatially of granite-related magmatic-hydrothermal origin $[54,55]$. However, minor tin deposits occur as sedimentary-exhalative (SEDEX) [56] and/or volcanogenic massive sulfide (VMS) deposits [57]. Cassiterites from granite-related tin deposits generally display variable colors, whereas cassiterites in VMS or SEDEX deposits are colorless. Compared with trace element compositions in cassiterite from VMS/SEDEX deposits, granite-related origin cassiterite generally contains an amount of Fe and $W$, which indicates that Fe and $\mathrm{W}$ are two effective indicators to distinguish those two types of tin mineralization [55,58]. Cassiterite from both skarn (Cst I-II) mineralization and the quartz vein (Cst III) mineralization at Dulong are characterized by elevated $\mathrm{W}$ and Fe concentrations, which mainly fall within the field of granite-related Sn deposits in the Fe vs. W binary discrimination plot (Figure 7a). The fact that scheelite skarn has also been discovered in the Dulong district [59] indicates an elevated $\mathrm{W}$ content in the magmatic-hydrothermal fluid [9]. It has been argued that cassiterite with low $\mathrm{F}$ and $\mathrm{Mn}$ and high $\mathrm{Nb}$ and Ta contents forms in high temperature systems such as granite and pegmatite, whereas cassiterite with elevated Fe and Mn and lowered $\mathrm{Nb}$ and $\mathrm{Ta}$ concentrations is favored in relatively low temperature hydrothermal environments $[9,10,45,55]$. Cassiterite from the Dulong Sn-Zn-In polymetallic deposit contain low $\mathrm{Nb}$ and Ta contents, which are plotted in the field of cassiterites in the epithermal hydrothermal deposits and are distinctly different from those high $\mathrm{Nb}$-Ta cassiterites in the rare element pegmatites (Figure 7b). It indicates that three types of cassiterite, Cst I (associated with magnetite), Cst II (associated with sulfide), and Cst III (occurs in quartz veins), all belong to hydrothermal systems associated with the Laojunshan granite.
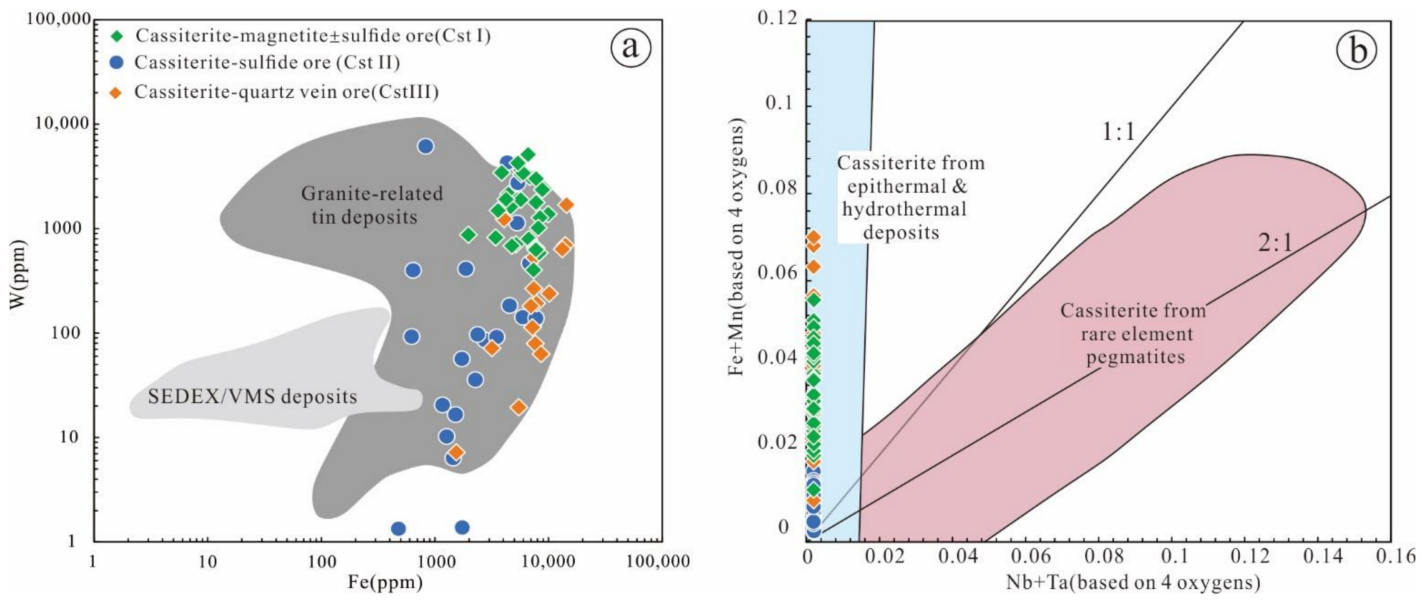

Figure 7. (a) Binary plot of Fe vs. $\mathrm{W}$ in cassiterite from the Dulong district (modified by [58]). (b) Covariation plot of $\mathrm{Nb}+$ Ta vs. Fe $+\mathrm{Mn}$ in cassiterite grains from the Dulong district (modified by [45]). 
The controlling factors for trace elements in hydrothermal cassiterites include temperature, pressure, $\mathrm{pH}$, Eh, fluid compositions, etc. [9]. The contents of high field strength elements (HFSEs: Zr, Nb, Ta, Hf) decrease from the skarn cassiterite (Cst I-II) to the quartz veins (Cst III) in the Dulong deposit. This distinct decrease in the content of HFSEs can be attributed to controlling factors governing the partitioning of these HFSEs elements between cassiterite and ore-forming fluid in the different mineralizing environments. One possibility for the change in HFSE solubility may be that skarn cassiterite formed under high temperature whereas the quartz vein cassiterite formed under a low temperature environment. It can be found from the Dulong ore blocks that porphyry formed at a shallower depth compared with concealed granite (Figure 2b). The formation of the porphyritic granite shows a relatively lower temperature environment relative to the inner medium- to fine-grained granite, which is supported by previous studies $[21,22,60]$. Thus, the formation of skarn cassiterite (Cst I-II) may be mainly related to the concealed granite and the formation of quartz vein cassiterite (Cst III) is mainly related to porphyry granite. In hydrothermal fluids, the HFSEs are activated as F-complexes, whose solubility depends on $\mathrm{pH}$, fluorine activity, temperature and pressure $[61,62]$. The decrease of temperature, and solubility of F-complex, can lead to lower HFSE contents in quartz vein cassiterites as opposed to skarn cassiterites.

\subsection{Mineralization Age of the Dulong Sn-Zn Polymetallic deposit}

Accurate and precise age determination of mineral deposits is important to a full understanding of ore genesis. Radioisotopic dating methods previously used to constrain the timing of mineralization and hydrothermal alteration in the Dulong district include biotite ${ }^{39} \mathrm{Ar}-{ }^{40} \mathrm{Ar}$, zircon $\mathrm{U}-\mathrm{Pb}$, and cassiterite $\mathrm{U}-\mathrm{Pb}$ analysis [21-24]. Recent studies employing ${ }^{39} \mathrm{Ar}-{ }^{40} \mathrm{Ar}$ dating of hydrothermal biotite yielded a plateau age of $86.28 \pm 0.52 \mathrm{Ma}$ (our own unpublished data). Meanwhile, LA-MC-ICPMS/SHRIMP U-Pb dating of cassiterite yielded ages between 79.8 and $97.5 \mathrm{Ma}$ [21-23]. These results suggest that the $\mathrm{Sn}$ mineralization at Dulong has a close relationship with the Laojunshan granite. However, whether multi-stage Sn mineralizations at Dulong are associated with the Laojunshan multi-phase pluton remains unclear.

In this study, three types of cassiterite were recognized in the Dulong district: Cst I-II occurs in skarn in $\mathrm{F}_{1}$ fault near the concealed granite, Cst III occurs in quartz veins near porphyritic granite, and Cst II is associated with sulfide (pyrrhotite, sphalerite; Figure 3b,f,g), from which we obtained a Cst II Tera-Wasserburg U-Pb Concordia age of $88.5 \pm 2.1 \mathrm{Ma}$ and with a weighted mean ${ }^{206} \mathrm{~Pb} /{ }^{238} \mathrm{U}$ ages of $87.1 \pm 1.6 \mathrm{Ma}$. Cst-III occurring in quartz veins (Figure 3c,h,i), with a Tera-Wasserburg U-Pb Concordia age of $82.1 \pm 6.3 \mathrm{Ma}$ and a weighted mean of ${ }^{206} \mathrm{~Pb} /{ }^{238} \mathrm{U}$ ages of $77.7 \pm 4.4 \mathrm{Ma}$ as obtained by LA-ICPMS. These U-Pb ages indicate that two Sn mineralization have been identified. This finding is supported by in situ trace element compositions in cassiterite. At Dulong, Cst I-II in the skarn near the concealed granite displays relatively high HFSEs (e.g., $\mathrm{Zr}, \mathrm{Nb}$, Ta, Hf) relative to Cst III in quartz veins. Additionally, the age of Cst II is comparable with phases one and two of the Laojunshan granites (83.3-92.9 Ma) with error, whereas the crystallization age of Cst III is similar to phase three of the Laojunshan granites (75.9-86.9 Ma) with error, respectively. It is suggested that at least two Sn mineralizations occur in the Dulong district. The two mineralization ages are consistent with the emplacement age of the Laojunshan granite $(75.9-92.9 \mathrm{Ma}[21,22,24])$ within error, suggesting a close temporal link between tin mineralization and granitic magmatism.

In conclusion, trace element characteristics and $\mathrm{U}-\mathrm{Pb}$ ages of cassiterite suggest that the formation of Cst I-II were mainly related to phases one and two granite whereas the formation of Cst III is mainly related to phase three porphyry granite.

\section{Conclusions}

The field geology, petrography, and in situ LA-ICPMS studies of cassiterite from the Dulong Sn-Zn-In polymetallic deposit presents the following conclusions: 
(1) Acid neutralizing muscovitization and pyroxene reactions could be one of the important mechanisms for the Sn precipitation via fluid-rock interaction.

(2) Tetravalent elements (e.g., Zr, Hf, Ti, U, W) are incorporated in cassiterite by direct substitution, other elements such as Fe enter cassiterite by coupled substitution with $\mathrm{OH}^{-}\left(\mathrm{Fe}^{3+}+\mathrm{OH}^{-}=\mathrm{Sn}^{4+}+\mathrm{O}^{2-}\right)$.

(3) Cst I-II have higher contents of activating luminescence elements $(\mathrm{Al}, \mathrm{Ti}, \mathrm{W})$ and quenching luminescence elements (Fe) than Cst III. Elevated W and Fe but low Zr, Hf, $\mathrm{Nb}$ and Ta concentrations in cassiterite from Dulong, which are distinctly different from those of cassiterites in VMS/SEDEX tin deposits, but similar to those from granite related tin deposits.

(4) In situ U-Pb dating of two cassiterite samples from Cst II and Cst III yielded TeraWasserburg U-Pb lower intercept ages of $88.5 \pm 2.1 \mathrm{Ma}$ and $82.1 \pm 6.3 \mathrm{Ma}$, with weighted mean ${ }^{206} \mathrm{~Pb} /{ }^{238} \mathrm{U}$ ages of $87.1 \pm 1.6 \mathrm{Ma}$ and $77.7 \pm 4.4 \mathrm{Ma}$, respectively. Compared with the emplacement age of the Laojunshan granite (75.9-92.9 Ma), the $\mathrm{U}-\mathrm{Pb}$ age and trace element characteristics of cassiterites reveal that Cst I-II within the proximal skarn is mainly related to concealed granite (Laojunshan granites of phases one and two) whereas Cst III is mainly associated with porphyritic granite.

Supplementary Materials: The following are available online at https:/ / www.mdpi.com/2075-163 X/11/2/199/s1, Table S1: Trace element compositions (ppm) of cassiterite by LA-ICP-MS from the Dulong Sn-Zn-In polymetallic deposit.

Author Contributions: Data curation, Y.C., and W.C.; formal analysis, W.C.; investigation, S.L., Y.L., L.Y., C.W. and Y.C.; project administration, W.C.; writing—original draft, S.L.; writing-review and editing, S.L., Y.L., L.Y. and C.W. All authors have read and agreed to the published version of the manuscript.

Funding: This study was funded by the National Key R \& D Program of China (2016YFC0600503), National Natural Science Foundation of China (41762012), Science and Technology Plan Project of Guizhou Province ([2017]5726-29) and Joint fund of Guizhou Normal University-Science and Technology Department ([2017]7361).

Institutional Review Board Statement: Not applicable.

Informed Consent Statement: Not applicable.

Data Availability Statement: Not applicable.

Acknowledgments: The authors thank Yunfeng Liu, Suoqing Zhang, and Qinfu Ye from the Yunan Hualian Zinc and Indium Stock., LTD in South Yunnan province and Wenbiao Wei from Yunnan Hualian Mineral Exploration Co. LTD for their help providing geological maps during fieldwork. We would like to acknowledge Yanwen Tang and Junjie Han from the State Key Laboratory of Ore Deposit Geochemistry (SKLODG), Institute of Geochemistry, Chinese Academy of Sciences (IGCAS) for their assistance the experiment.

Conflicts of Interest: The authors declare no conflict of interest.

\section{References}

1. Lehmann, B. Metallogeny of Tin; Springer: Berlin/Heidelberg, Germany, 1990.

2. Heinrich, C.A. The chemistry of tin (-tungsten) ore deposition. Econ. Geol. 1990, 85, 529-550. [CrossRef]

3. Heinrich, C.A. Geochemical evolution and hydrothermal mineral deposition in Sn(-W-base metal) and other granite related ore systems: Some conclusions from Australian examples. In Magmas, Fluids and Ore Deposits. Mineralogical Association of Canada Short Course Series; Mineralogical Association of Canada: Quebec, QC, Canada, 1995; Volume 23, pp. $203-220$.

4. Schneider, H.J.; Dulski, P.; Luck, J.; Moeller, P.; Villalpando, A. Correlation of trace element distribution in cassiterites and geotectonic position of their deposits in Bolivia. Miner. Depos. 1978, 13, 119-122. [CrossRef]

5. Moore, F.; Howie, R.A. Geochemistry of some Cornubian cassiterites. Miner. Depos. 1979, 14, 103-107. [CrossRef]

6. Cheng, Y.B.; Spandler, C.; Kemp, A.; Mao, J.W.; Rusk, B.; Hu, Y.; Blake, K. Controls on cassiterite $\left(\mathrm{SnO}_{2}\right)$ crystallization: Evidence from cathodoluminescence, trace-element chemistry, and geochronology at the Gejiu tin district. Am. Miner. 2019, 104, 118-129. [CrossRef] 
7. Giuliani, G. La cassiterite zonée du gisement de Sokhret Allal (Granite des Zaer, Maroc Central): Composition chimique et phases fluides associées. Miner. Depos. 1987, 22, 253-261. [CrossRef]

8. Möller, P.; Dulski, P.; Szacki, W.; Malow, G.; Riedel, E. Substitution of tin in cassiterite by tantalum, niobium, tungsten, iron and manganese. Geochim. Cosmochim. Acta 1988, 52, 1497-1503. [CrossRef]

9. Guo, J.; Zhang, R.Q.; Li, C.; Sun, W.; Hu, Y.; Kang, D.; Wu, J. Genesis of the Gaosong Sn-Cu deposit, Gejiu district, SW China: Constraints from in situ LA-ICP-MS cassiterite U-Pb dating and trace element fingerprinting. Ore Geol. Rev. 2018, 92, 627-642. [CrossRef]

10. Nambaje, C.; Eggins, S.M.; Yaxley, G.M.; Sajeev, K. Micro-characterisation of cassiterite by geology, texture and zonation: A case study of the Karagwe Ankole Belt, Rwanda. Ore Geol. Rev. 2020, 124, 103609. [CrossRef]

11. Stein, H.J.; Markey, R.J.; Morgan, J.W.; Du, A.; Sun, Y. Highly precise and accurate Re-Os ages for molybdenite from the East Qinling molybdenum belt, Shaanxi Province, China. Econ. Geol. 1997, 92, 827-835. [CrossRef]

12. Yuan, S.D.; Peng, J.T.; Hao, S.; Li, H.M.; Geng, J.Z.; Zhang, D.L. A precise U-Pb age on cassiterite from the Xianghualing tin-polymetallic deposit (Hunan, South China). Miner. Depos. 2008, 43, 375-382. [CrossRef]

13. Chiaradia, M.; Vallance, J.; Fontboté, L.; Stein, H.; Schaltegger, U.; Coder, J.; Richards, J.; Villeneuve, M.; Gendall, I. U-Pb, Re-Os, and 40Ar/39Ar geochronology of the Nambija Au-skarn and Pangui porphyry Cu deposits, Ecuador: Implications for the Jurassic metallogenic belt of the Northern Andes. Miner. Depos. 2009, 44, 371-387. [CrossRef]

14. Li, J.W.; Deng, X.D.; Zhou, M.F.; Liu, Y.S.; Zhao, X.F.; Guo, J.L. Laser ablation ICPMS titanite U-Th-Pb dating of hydrothermal ore deposits: A case study of the Tonglushan Cu-Fe-Au skarn deposit, SE Hubei Province, China. Chem. Geol. 2010, $270,56-67$. [CrossRef]

15. Chen, X.C.; Hu, R.Z.; Bi, X.W.; Li, H.M.; Lan, J.B.; Zhao, C.H.; Zhu, J.J. Cassiterite LA-MC-ICP-MS U/Pb and muscovite 40Ar/39Ar dating of tin deposits in the Tengchong-Lianghe tin district, NW Yunnan, China. Miner. Depos. 2014, 49, 843-860. [CrossRef]

16. Cox, R.A.; Wilton, D.H.C.; Košler, J. Laser-ablation U-Th-Pb in situ dating of zircon and allanite: An example from the October Harbour granite, central Coastal Labrador, Canada. Can. Miner. 2003, 41, 273-291. [CrossRef]

17. Cox, R.A.; Wilton, D.H.C. U-Pb dating of perovskite by LA-ICP-MS: An example from the Oka carbonatite, Quebec, Canada. Chem. Geol. 2006, 235, 21-32. [CrossRef]

18. Yuan, S.D.; Peng, J.T.; Hao, S.; Li, H.M.; Geng, J.Z.; Zhang, D.L. In situ LA-MC-ICPMS and ID-TIMS U-Pb geochronology of cassiterite in the giant Furong tin deposit, Hunan Province, South China: New constraints on the timing of tin-polymetallic mineralization. Ore Geol. Rev. 2011, 43, 235-242. [CrossRef]

19. Che, X.D.; Wu, F.Y.; Wang, R.C.; Gerdes, A.; Ji, W.Q.; Zhao, Z.H.; Yang, J.H.; Zhu, Z.Y. In situ U-Pb isotopic dating of columbitetantalite by LA-ICP-MS. Ore Geol. Rev. 2015, 65, 979-989. [CrossRef]

20. Roberts, N.M.W.; Walker, R.J. U-Pb geochronology of calcite-mineralized faults:absolute timing of rift-related fault events on the northeast Atlantic margin. Geology 2016, 44, 531-534. [CrossRef]

21. Zhao, Z.Y.; Hou, L.; Ding, J.; Zhang, Q.M.; Wu, S.Y. A genetic link between late cretaceous granitic magmatism and sn mineralization in the southwestern south china block: A case study of the dulong Sn-dominant polymetallic deposit. Ore Geol. Rev. 2018, 93, 268-289. [CrossRef]

22. Liu, Y.P.; Li, Z.; Li, H.; Guo, L.; Xu, W.; Ye, F.; Li, C.; Pi, D. U-Pb geochronology of cassiterite and zircon from the Dulong deposit:evidence for Cretaceous large-scale granitic magmatism and mineralization events in southeastern Yunnan Province, China. Acta Pet. Sin. 2007, 23, 967-976, (In Chinese with English abstract).

23. Wang, X.; Liu, Y.; Miao, Y.; Bao, T.; Ye, L.; Zhang, Q. In LA-MC-ICP-MS cassiterite U-Pb dating of Dulong Sn-Zn polymetallic deposit and its significance. Acta Petrol. Sin. 2014, 30, 867-876, (In Chinese with English abstract).

24. Xu, B.; Jiang, S.Y.; Wang, R.; Ma, L.; Zhao, K.; Dong, Y.X. Late cretaceous granites from the giant dulong sn-polymetallic ore district in yunnan province, south china: Geochronology, geochemistry, mineral chemistry and nd-hf isotopic compositions. Lithos 2015, 218, 54-72. [CrossRef]

25. Zhou, H.; Qi, X. Extremely Low Grade Metamorphism: A Case Study of the Mesozoic Metamorphic Belt in Youjiang Basin; Geological Publishing House: Beijing, China, 1999; pp. 1-66. (In Chinese)

26. Liu, Y.P.; Ye, L.; Li, C.Y.; Song, B.; Li, T.S.; Guo, L.G.; Pi, D.H. Discovery of the Neoproterozoic magmatics in southeastern Yunnan: Evidence from SHRIMP zircon U-Pb dating and lithogeochemistry. Acta Pet. Sin. 2006, 22, 916-926, (In Chinese with English abstract).

27. Guo, L.G.; Liu, Y.P.; Li, C.Y.; Xu, W.; Ye, L. SHRIMP zircon U-Pb geochronology and lithogeochemistry of Caledonian Granites from the Laojunshan area, southeastern Yunnan province, China: Implications for the collision between the Yangtze and Cathaysia blocks. Geochem. J. 2009, 43, 101-122. [CrossRef]

28. Yan, D.P.; Zhou, M.F.; Wang, C.Y.; Xia, B. Structural and geochronological constraints on the tectonic evolution of the Dulong-Song Chay tectonic dome in Yunnan province, SW China. J. Asian Earth Sci. 2006, 28, 332-353. [CrossRef]

29. Zhang, R.; Lehmann, B.; Seltmann, R.; Li, C.; Sun, W. Cassiterite U-Pb geochronology constrains magmatic-hydrothermal evolution in complex evolved granite systems: The classic Erzgebirge tin province (Saxony and Bohemia). Geology 2017, 45, 1095-1098. [CrossRef]

30. Zhang, R.; Lu, J.; Lehmann, B.; Li, C.; Li, G.; Zhang, L.; Guo, J.; Sun, W. Combined zircon and cassiterite U-Pb dating of the Piaotang granite-related tungsten-tin deposit, southern Jiangxi tungsten district, China. Ore Geol. Rev. 2017, 82, 268-284. [CrossRef] 
31. Liu, Y.S.; Hu, Z.C.; Gao, S.; Güther, D.; Xu, J.; Gao, C.G.; Chen, H.H. In situ analysis of major and trace elements of anhydrous minerals by LA-ICP-MS without applying an internal standard. Chem. Geol. 2008, 257, 34-43. [CrossRef]

32. Liu, Y.S.; Hu, Z.C.; Zong, K.Q.; Gao, C.G.; Gao, S.; Xu, J.; Chen, H.H. Reappraisement and refinement of zircon U-Pb isotope and trace element analyses by LA-ICP-MS. Chin. Sci. Bull. 2010, 55, 1535-1546. [CrossRef]

33. Kelly, W.C.; Turneaure, F.S. Mineralogy, paragenesis and geothermometry of the tin and tungsten deposits of the Eastern Andes, Bolivia. Econ. Geol. 1970, 65, 609-680. [CrossRef]

34. Jackson, N.J.; Willis-Richards, J.; Manning, D.A.C.; Sams, M.S. Evolution of the Cornubian Ore Field, Southwest England: Part II. Mineral deposits and ore-forming processes. Econ. Geol. 1989, 84, 1101-1133. [CrossRef]

35. Wagner, T.; Mlynarczyk, M.S.J.; Williams-Jones, A.E.; Boyce, A.J. Stable isotope constraints on ore formation at the San Rafael tin-copper deposit, southeast Peru. Econ. Geol. 2009, 104, 223-248. [CrossRef]

36. Neiva, A.M.R. Geochemistry of cassiterite and wolframite from tin and tungsten quartz veins in Portugal. Ore Geol. Rev. 2008, 33, 221-238. [CrossRef]

37. Eugster, H.P.; Wilson, G.A. Transport and deposition of ore-forming elements in hydrothermal systems associated with granites. In High Heat Production (HHP) Granites, Hydrothermal Circulation and Ore Genesis; Halls, C., Ed.; Institution of Mining and Metallurgy: London, UK, 1985; pp. 87-98.

38. Eugster, H.P. Granites and hydrothermal ore-deposits-A geochemical framework. Miner. Mag. 1985, 49, 7-23. [CrossRef]

39. Plimer, I.R.; Lu, J.; Kleeman, J.D. Trace and rare earth elements in cassiterite-sources of components for the tin deposits of the Mole Granite, Australia. Miner. Depos. 1991, 26, 267-274. [CrossRef]

40. Murciego, A.; Sanchez, A.G.; Dusausoy, Y.; Pozas, J.M.M.; Ruck, R. Geochemistry and EPR of cassiterites from the Iberian Hercynian Massif. Miner. Mag. 1997, 61, 357-365. [CrossRef]

41. Shannon, R.D. Revised effective ionic radii and systematic studies of interatomic distances in halides and chalcogenides. Acta Crystallogr. 1976, A32, 751-767. [CrossRef]

42. Hoskin, P.W.O. The Composition of Zircon and Igneous and Metamorphic Petrogenesis. Rev. Miner. Geochem. 2003, 53, 27-62. [CrossRef]

43. Münker, C.; Pfänder, J.A.; Weyer, S.; Büchl, A.; Kleine, T.; Mezger, K. Evolution of planetary cores and the Earth-Moon system from $\mathrm{Nb}$ /Ta systematics. Science 2003, 301, 84-87. [CrossRef]

44. Cerný, P.; Ercit, T.S. Some recent advances in the mineralogy and geochemistry of $\mathrm{Nb}$ and Ta in rare-element granitic pegmatites. Bull. Minéral. 1985, 108, 499-532. [CrossRef]

45. Tindle, A.G.; Breaks, F.W. Oxide minerals of the separation rapids rare-element granitic pegmatite group, northwestern Ontario. Can. Miner. 1998, 36, 609-635.

46. Pieczka, A.; Golebiowska, B.; Parafiniuk, J. Geochemistry and origin of the cassiterite from Redziny, lower Silesia, Poland. Mineralogia 2007, 38, 219-230. [CrossRef]

47. Sippel, R.F. Sandstone petrology, evidence from luminescence petrography. J. Sediment. Res. 1968, 38, 530-554. [CrossRef]

48. Rusk, B.; Reed, M. Scanning electron microscopecathodoluminescence analysis of quartz reveals complex growth histories in veins from the Butte porphyry copper deposit, Montana. Geology 2002, 30, 727-730. [CrossRef]

49. Mao, W.; Rusk, B.; Yang, F.; Zhang, M. Physical and chemical evolution of the Dabaoshan porphyry Mo deposit, South China: Insights from fluid inclusions, cathodoluminescence, and trace elements in quartz. Econ. Geol. 2017, 112, 889-918. [CrossRef]

50. Mao, W.; Zhong, H.; Zhu, W.G.; Lin, X.G.; Zhao, X.Y. Magmatichydrothermal evolution of the Yuanzhuding porphyry Cu-Mo deposit, South China: Insights from mica and quartz geochemistry. Ore Geol. Rev. 2018, 101, 765-784. [CrossRef]

51. Remond, G. Exemples d'identification et de localisation des elements entrace dans les mineraux luminescents a l'aide de la microsonde ionique. Bull. Société Française Minéralogie Cristallogr. 1973, 96, 183-198. [CrossRef]

52. Farmer, C.B.; Searl, A.; Halls, C. Cathodoluminescence and growth of cassiterite in the composite lodes at South Crofty mine, Cornwall, England. Miner. Mag. 1991, 55, 447-458. [CrossRef]

53. Steveson, B.G.; Taylor, R.G. Trace element content of some cassiterites from Eastern Australia. Proc. R. Soc. Qld. 1973, 84, 43-54.

54. Hosking, K.F.G. The world's major types of tin deposits. In Geology of Tin Deposits in Asia and the Pacific; Springer: Berlin, Heidelberg, 1988; pp. 3-49.

55. Taylor, R.G. Geology of Tin Deposits; Elsevier: Amsterdam, The Netherlands, 1979; pp. 1-543.

56. Hamilton, J.M.; Bishop, D.T.; Morris, H.C.; Owens, O.E. Geology of the Sullivan orebody, Kimberley, BC, Canada. Precambrian Sulphide Deposits; Special Paper; Geological Association of Canada: Toronto, Canada, 1982; Volume 25, pp. 597-665.

57. Oliveira, J.T.; Pacheco, N.; Carvalho, P.; Ferreira, A. The Neves Corvo mine and the Paleozoic geology of southwest Portugal. Geology and VMS Deposits of the Iberian Pyrite belt. In Proceedings of the SEG Neves Corvo Field Conference, Libson, Portugal, 11-14 May 1997; pp. 21-71.

58. Hennigh, Q.; Hutchinson, R.W. Cassiterite at Kidd Creek: An example of volcanogenic massive sulfide-hosted tin mineralization. Econ. Geol. Monogr. 1999, 10, 431-440.

59. Ye, L.; Bao, T.; Liu, Y.P.; He, F.; Wang, X.J.; Zhang, Q.; Wang, D.P.; Lan, J.B. The trace and rare elements in scheelites and their implication for the mineralization in Dulong Sn-Zn polymetal ore deposit, Yunnan Province. J. Nanjing Univ. (Nat. Sci.) 2018, $54,245-258$.

60. Liu, S.Y.; Liu, Y.P.; Ye, L.; Su, G.L. A Study on Metallogenic Temperature Field of The Dulong Sn-Zn Polymetallic Deposit. Acta Miner. Sin. 2018, 3, 280-289, (Chinese with english abstracts). 
61. Aja, S.U.; Wood, S.A.; Williams-Jones, A.E. The aqueous geochemistry of Zr and the solubility of some zirconium-bearing minerals. Appl. Geochem. 1995, 10, 603-620. [CrossRef]

62. Aja, S.U.; Wood, S.A.; Williams-Jones, A.E. The solubility of some Alkali-Bearing Zr minerals in hydrothermal solutions. MRS Proc. 1996, 432. [CrossRef] 